\title{
Influence of Limestone and Fly Ash (Class F) as Partial Replacement Materials on the Mechanical Properties of Concrete
}

\author{
Pathan Maaz Khan L. ${ }^{1}$, Farhan A. Vahora ${ }^{2}$ \\ ${ }^{1}$ Department of M.E Structure Gujarat Technological University, India \\ ${ }^{2}$ Assistant Professor, L.J Institute of Engineering \& Technology, Ahmedabad, India
}

\begin{abstract}
The present study attempts to investigate the influence of partial replacement of Limestone with crushed coarse aggregate and Fly ash (Class $F$ ) with fine aggregate (Sand) on the mechanical properties of concrete compared with the conventional concrete. because the great expansion in building houses, industrial projects and service projects resulted in great and continuous demand of crushed coarse aggregate and sand and on the other hand shortage of them because of environmental condition need an alternative materials. In this project, A mix design is done for M20 grade of concrete using mix proportion (1: 1.71: 3.08) by IS method to investigate the strength of concrete mix at 7 and 28 days age containing $0 \%, 15 \%, 30 \%$ \& $45 \%$ of fine aggregate by fly ash (Class $F$ ) and $0 \%, 25 \%, 50 \%$ \& $100 \%$ of coarse aggregate materials by limestone. Compressive strength, splitting tensile strength, flexural tensile strength, durability and workability tests are performed.
\end{abstract}

Keywords: Limestone, Fly ash, Compressive strength, Flexural tensile strength

\section{Introduction}

The demand for aggregates is increasing rapidly and so as the demand of concrete. To meet the global demand of concrete in the future, it becoming a more challenging task to find suitable alternatives of sand and crushed coarse aggregates for preparing concrete which are used as aggregates in concrete. Therefore the use of alternative sources for natural aggregates is becoming increasingly important. So, we have to select the materials which are available in plenty of quantity and that can be used as alternative source or partial replacement of aggregates with certain benefits as environment friendly, economical and provide higher strength than sand and crushed coarse aggregates commonly used as fine and coarse aggregate. One such alternative is Limestone in replacement with coarse aggregates and fly ash (Class F) in replacement with natural sand. The use of Limestone in concrete is desirable because of benefits such as lighter in weight, reducing environmental pollution and good strength. While the use of fly ash in concrete is desirable because of benefits such as increased workability, reduction of cement consumption and decreased permeability. Fly ash is generally used as replacement of cement, as an admixture in concrete but fly ash (Class F) could be very conveniently used as a partial replacement of sand in structural concrete. The main objective of this project is to find the good replacements for sand and coarse aggregate in concrete, because the great expansion in building houses, industrial projects and service projects resulted in great and continuous demand of gravel and sand and on the other hand shortage of natural river sand and gravel because of environmental condition need an alternative materials

\section{Limestone}

Limestone is an important raw material and it is often said to be the world's most versatile mineral. Limestone is an aggregate of calcium carbonate $(\mathrm{CaCo} 3)$, carbonate of calcium and magnesium or the mixture of the two. If magnesium is present up to 20 per cent it is called magnesium limestone and if it is above 20 per cent it is known as dolomite limestone. Limestone deposits are of sedimentary origin. About $10 \%$ of the total volume of all sedimentary rock on earth is limestone.

The addition of limestone in concrete reduces the initial and final setting time, as well as porosity, whereas free lime and combined water increase with increasing limestone content. The quality of the limestone filler affects the performance of the cement in concrete and the water demand of the cement. Limestone is naturally available, cheap and it basic raw material in many industries.

Crushed limestone has several important advantages over river gravel as an aggregate for concrete.

(1) Limestone aggregates improve Strength.

For a given amount of cement in the mix, crushed limestone concrete will have an approximately $10 \%$ strength advantage. This strength advantage is due to that cement bonds tighter to limestone than to a slick/smooth gravel and the strength that is derived from the sharp angular faces of the crushed aggregate

(2) Limestone aggregates are lighter and easy to saw.

The Unit weight of crushed limestone is lighter than gravel; thus to mix a cubic yard of concrete, it will require about $12 \%$ less crushed limestone than gravel. Additionally, crushed limestone concrete is easier to saw through than gravel concrete. This is because most gravel is silica. Silica is almost impossible to cut with a steel saw.

(3) Limestone aggregates reduce the occurrence of cracking. The thermal coefficient of expansion of crushed limestone concrete is lower than gravel concrete. This means that slabs poured with limestone concrete will expand and contract less compared to gravel concrete for a given change in temperature. Studies have shown that this thermal stability 


\section{International Journal of Science and Research (IJSR) \\ ISSN (Online): 2319-7064}

Index Copernicus Value (2013): 6.14 | Impact Factor (2015): 6.391

coupled with limestone's superior curing properties results in greater crack spacing, and less crack width.

(4) Limestone aggregates reduce environment pollution.

The production of limestone fillers requires much less energy than cement production which also means that the carbon dioxide is much lower in limestone production than cement production. Limestone fillers result in more stable concrete quality thus reducing the amount of waste and improving durability which leads to a longer lifetime for concrete.

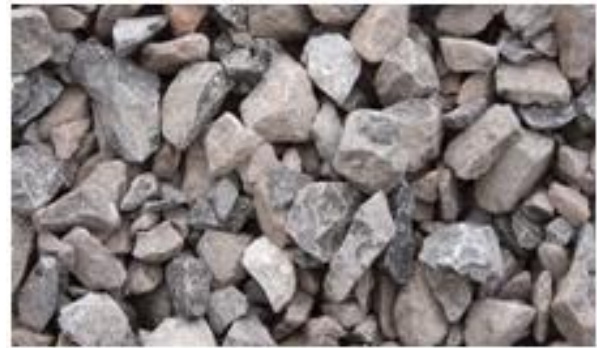

Figure 1: Limestone

Fly ash

Fly ash is a byproduct of power generation in coal fired power stations. Within a power station, coal is fed to a series of mills that pulverize the coal to a very fine powder. This powder is then fed into a boiler which combusts the coal to produce heat, that is then used to produce steam required for power generation. Heavier ash particles (bottom ash or slag) fall to the bottom of the burning chamber and the lighter ash particles (Fly Ash) fly out with the exhaust gas, thus the term Fly Ash. Before leaving the stack, these Fly Ash particles are removed and collected by electrostatic precipitators, bag houses or other methods. Two types of fly ash are commonly used in concrete: Class $\mathrm{C}$ and Class $\mathrm{F}$.

It is a pressing need today for the concrete industry to produce concrete with lower environmental impact. One way to achieve this is by reducing the use of natural aggregates (sand) in concrete whose resources are limited and are exhausting very fast. It can be also achieved by utilizing maximum possible waste materials like fly ash in concrete. As because of increased awareness of all ill effects of pollution, utilization and safe disposal of fly ash generated at thermal power plants has become an urgent and challenging task.

Fly ash is generally used as replacement of cement, as an admixture in concrete and in manufacture of cement. Enough studies have been carried out on partial replacement of cement by fly ash by earlier researchers. Fly ash could be very conveniently used as a partial replacement of sand in structural concrete. An increase in fly ash content results in higher strength for a given density, as fly ash is of pozzolonic nature.

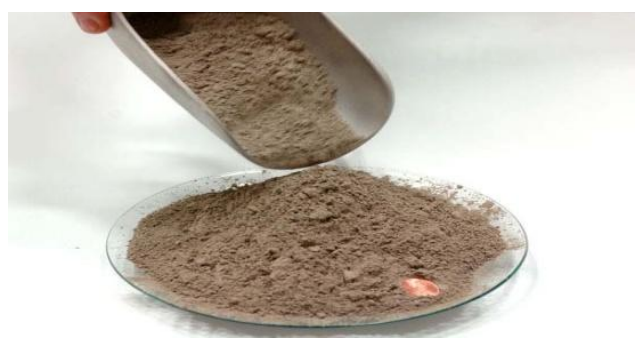

Source:(http://www.caer.uky.edu/kyasheducation/glossary.s $\underline{\mathrm{html}})$

\section{Objective and Scope}

The main objectives of this study is to find the good replacement for sand and gravel in concrete, because the great expansion in building houses, industrial projects and service projects resulted in great and continuous demand of them, and to study the Limestone properties related to strength and its performances as partial replacement with coarse aggregates and to investigate the strength performance of concrete produced by replacing natural sand by fly ash without sacrificing the strength and workability of concrete.

The main scope of this study is to produce the number of combinations of the concrete mix by replacing the fine aggregate (sand) in varying proportions with the Fly ash (Class F) and also by replacing the coarse aggregate (Gravel) in varying proportions with limestone to develop the mix design for concrete. Tests for research work has been restricted to Workability test, Compressive strength test, Split tensile strength test, Flexural strength, Durability test by Water Absorption of M20 grade concrete with Ordinary Portland cement.

\section{Literature Review}

Mazin T. Quttan, Ali Hussain Ali, Eman A. Qasim used Crushed Limestone in preparing and casting concrete blocks of $(15 \times 20 \times 40) \mathrm{cm}$. in size, using a mix proportion of $(1: 1.5$ : 3), and w/c $=0.5$ (by weight), whose cement content was (400) $\mathrm{kg} / \mathrm{m} 3$ and Compressive Strength, Unit Weight (Density), and Absorption Capacity tests of the concrete blocks were done. This study showed that a medium weight concrete of a desirable compressive strength may be obtained, using the crushed limestone as coarse aggregate. The absorption capacity and unit weight of the crushed limestone concrete is lower than that of the river gravel concrete. The workability of the crushed limestone concrete is lower than that of river gravel Concrete leading to high cohesiveness and lower the ability of the mix to bleed and segregate. In order to increase the workability of the mix, it is preferable to increase the materials finer than sieves (No. 30, No. 50, and No. 100), as well as, by using a certain types of admixture named Plasticizers.

Turan OZTURAN, Cengizhan Cecen used Limestone, basalt and gravel in replacement with coarse aggregate in concrete and tests were carried out to study the effect of the type of coarse aggregate on the compressive, flexural and splitting tensile strength on concrete produced at different strength levels. This study showed that normal strength concretes made with basalt and gravel gave similar compressive strengths while the concrete containing limestone attained somewhat higher strength. Higher Compressive, flexural and splitting tensile strengths about 10 to $20 \%$ were obtained with crushed basalt and limestone compared to the gravel aggregate when used in high strength concrete. The comparatively higher strength of the concrete made with limestone may be due to interfacial chemical reactions between the cement paste and the coarse aggregate particles. 


\section{International Journal of Science and Research (IJSR) \\ ISSN (Online): 2319-7064}

Index Copernicus Value (2013): 6.14 | Impact Factor (2015): 6.391

Rafat Siddique carried out an experimental investigation to evaluate the mechanical properties of concrete mixtures in which fine aggregate (sand) was partially replaced with Class F fly ash. Here six mixture proportions for M20 grade of concrete were made. First was control mix (with out fly ash), and the other five mixes contained Class F fly ash. Fine aggregate (sand) was replaced with five percentages $(10 \%$, $20 \%, 30 \%, 40 \%$, and $50 \%$ ) of Class $\mathrm{F}$ fly ash by weight. Tests were performed for properties of fresh concrete. Compressive strength, splitting tensile strength, flexural strength, and modulus of elasticity were determined at 7,14 , $28,56,91$, and 365 days.

This study showed that compressive strength, splitting tensile strength, flexural strength, and modulus of elasticity of fine aggregate (sand) replaced fly ash concrete specimens were higher than the plain concrete (control mix) specimens and the maximum value of them was observed with $50 \%$ fly ash content at all the ages. Results of this investigation suggest that Class F fly ash could be very conveniently used in structural concrete.

Aruna Kanthi E. and Kavitha $\mathbf{M}$ used fly ash as sand replacement material for M20 grade of concrete with a mix proportion of $1: 1.58: 3.2$ and $\mathrm{W} / \mathrm{C}$ ratio of 0.48 . Here, Fine aggregate (sand) was replaced with five percentages $(20 \%$, $40 \%, 60 \%, 80 \%$ and $100 \%$ ) of Class F fly ash by weight. Strength characteristics such as compressive strength split tensile strength and modulus of elasticity of concrete mixes are found out for 7, 14 and 28 days curing period and results are analyzed. This test results showed that the compressive and split tensile strengths increase with increase in fly ash percentage in the concrete mix up to $40 \%$ and decreases beyond $40 \%$ while the modulus of elasticity of concrete increases up to $60 \%$ replacement of sand with fly ash and it decreases beyond $60 \%$. The replacement of sand with fly ash up to $50 \%$ is beneficial for the concrete works.

\section{Materials}

\section{A. Cement}

The cement used in this experimental work is 53 grades Ordinary Portland Cement. The specific gravity of the cement is 3.15 . The initial and final setting times were found as 72 minutes and 180 minutes respectively.

\section{B. Fine Aggregate}

Locally available sand passed through $4.75 \mathrm{~mm}$ IS sieve is used. The specific gravity of fine aggregate is taken as 2.75 .

\section{Coarse Aggregate}

Crushed aggregate available from local sources has been used. The coarse aggregates with a maximum size of $20 \mathrm{~mm}$ having the specific gravity value of 2.68 are used as coarse aggregate.

\section{Limestone}

The Limestone used in this project is obtained from The Maruti Lime and Chemical Industry (website: www.marutilime.com ) which is from one of the leading companies in Rajasthan and is well known for the chips of the limestone.
Table 1: Physical Properties of Limestone

\begin{tabular}{|c|c|c|}
\hline Sr. No. & Properties & Value \\
\hline 1. & Water absorption & $0.6 \%$ \\
\hline 2. & Specific gravity (G) & 2.75 \\
\hline 3. & Fineness by wet sieving retained on 12.5 micron & $0.59 \%$ \\
\hline
\end{tabular}

Table 2: Chemical Properties of Limestone

\begin{tabular}{|c|c|c|}
\hline Sr. No. & Properties & Value \\
\hline 1. & Lime $(\mathrm{CaO})$ & $38-42 \%$ \\
\hline 2. & Silica $\left(\mathrm{SiO}_{2}\right)$ & $15-18 \%$ \\
\hline 3. & Aluminum $\left(\mathrm{Al}_{2} \mathrm{O}_{3}\right)$ & $3-5 \%$ \\
\hline 4. & $\mathrm{MgO}$ & 0.5 to $3 \%$ \\
\hline 5. & $\mathrm{FeO}+\mathrm{Fe}_{2} \mathrm{O}_{3}$ & $1-1.5 \%$ \\
\hline 6. & Loss on ignition & $30-32 \%$ \\
\hline
\end{tabular}

\section{E. Fly ash}

Class F fly ash has pozzolanic properties. In this experimental work, low calcium, Class F dry fly ash obtained from the Thermal Power Station Torrent Power Limited, Sabarmati, Ahmadabad is used.

Table 3: Physical Properties of Fly ash

\begin{tabular}{|c|c|c|}
\hline Sr. No. & Properties & Value \\
\hline 1. & Specific gravity & 2.14 \\
\hline 2. & Water Absorption & $21.4 \%$ \\
\hline 3. & Moisture content & $2.5 \%$ \\
\hline 4. & Material Passing $0.045 \mathrm{~mm}$ sieve & $7.03 \%$ \\
\hline
\end{tabular}

\section{Methodology}

The casting of the concrete is one of the most important methods which make the concrete more compact and good for the workability and strength. Batching, mixing and casting operations are carefully done.

\section{A. Mixing}

The materials are weighted first with an accuracy of 0.5 grams on the weighting machine as per the mix design by IS specification. For the material to be mixed, the drum type of the mixture is used.

\section{B. Moulding and Vibrating}

The cube mould having the size $(150 \times 150 \times 150) \mathrm{mm}$, the cylinder mould having the size $(150 \times 300) \mathrm{mm}$ and the beam mould with size $(150 \times 150 \times 700) \mathrm{mm}$ are used in the casting of this project. Compaction is given to the cube and cylinder moulds using a standard tamping bar at every 50 $\mathrm{mm}$ layer with 35 strokes at each layer of concrete. And vibration is given to the beam moulds using machine vibrator.

\section{De-moulding and Curing}

After 24 hours of the casting, the specimens are de-moulded and are transferred to curing tank where in they are allowed to cure for $7, \& 28$ days.

\section{Experimental Program}

From the study of research papers we conclude that Crushed limestone can be used satisfactorily as coarse aggregate for making a good quality concrete of a desirable compressive strength and the replacement of natural sand with fly ash up to $50 \%$ is beneficial for the concrete works to achieve 


\section{International Journal of Science and Research (IJSR) \\ ISSN (Online): 2319-7064 \\ Index Copernicus Value (2013): 6.14 | Impact Factor (2015): 6.391}

strength, economy and to achieve problem of waste disposal. In this project, All the materials are weighed as per mix proportion of $1: 1.78: 3.2$ with a W/C ratio of 0.50 which correspond to M20 grade of concrete. Two different variants of mixes are made. Variant $\mathrm{A}$ is concrete mix with varying proportion of Fly ash (15\%, 30\% and 45\%) without replacing of the limestone. Variant $\mathrm{B}$ is by taking the optimum proportion of fly ash and the varying proportion of limestone $(25 \%, 50 \%, 75 \%$, and $100 \%)$. The specimen will be tested for the 7 and 28 days.

Mix proportion for the Mix Design is

\begin{tabular}{|c|c|c|c|c|}
\hline & \multicolumn{4}{|c|}{ Mix Proportions $(\mathrm{Kg} / \mathrm{m} 3)$} \\
\hline W/C Ratio & Water & Cement & Sand & Aggregates \\
\hline 0.5 & 191.6 & 383.2 & 656.35 & 1180.06 \\
\hline
\end{tabular}

\section{Results}

\section{A. Slump test Results}

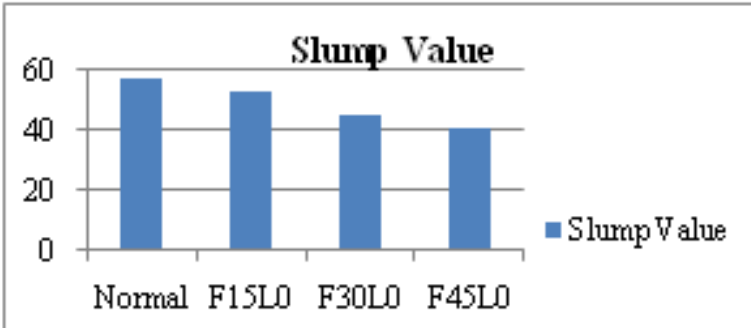

Figure 2: Slump test Results of fly ash Replacements

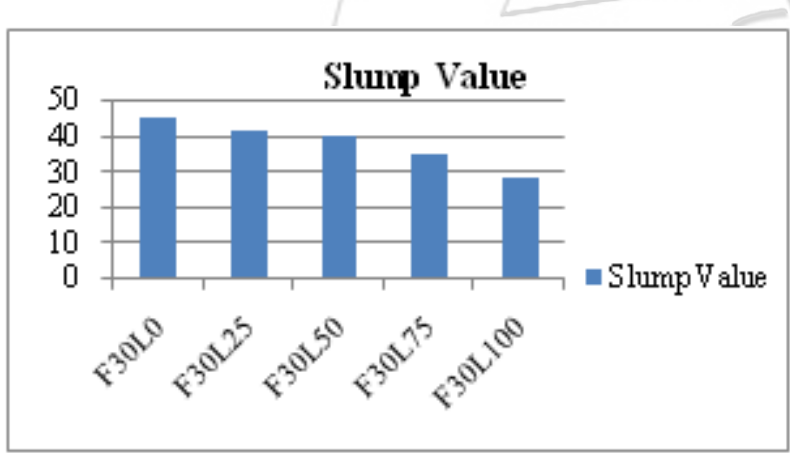

Figure 3: Slump test Results of optimum fly ash and varying Limestone Replacements

From the figures 2 and 3 it is observed that the value of slump decreases as the fly ash replacement percentage and limestone replacement percentage increases in concrete mix.

\section{B. Compressive strength Test Results}

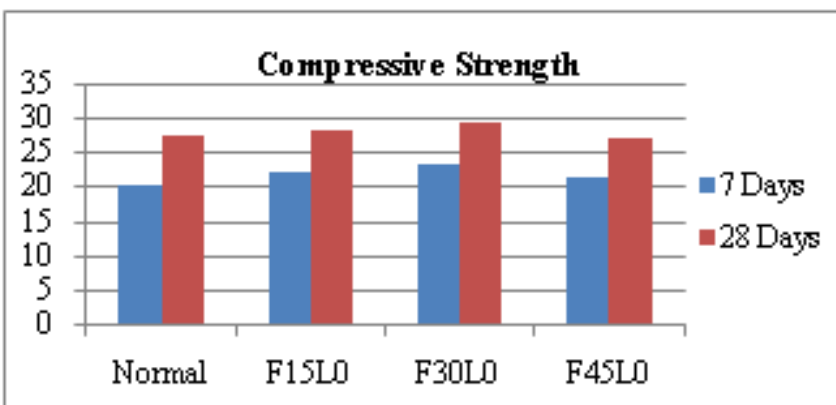

Figure 4: Compressive strength test Results of fly ash Replacements

From the Fig. 4 it is observed that the value of compressive strength of cubes increase for the fly ash replacement percentage up to $30 \%$ and then for $45 \%$ fly ash replacement, the compressive strength decrease for both $7 \& 28$ days.

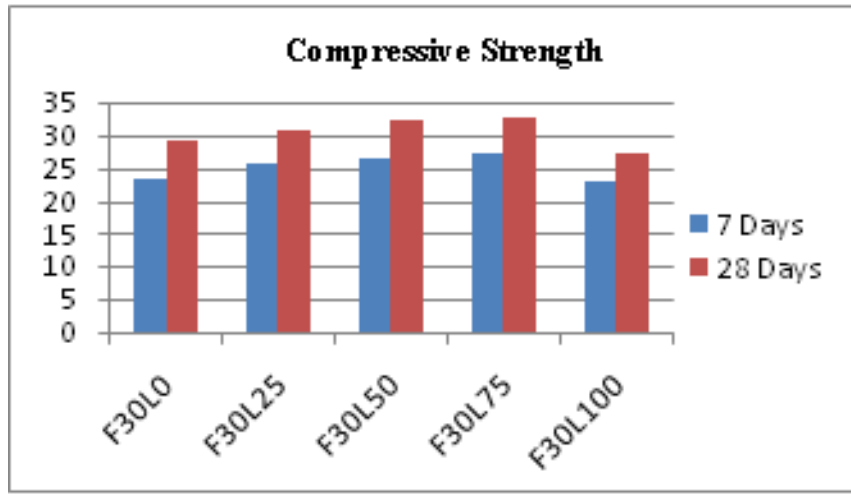

Figure 5: Compressive strength of optimum fly ash and varying Limestone Replacements

From the Fig. 5 it is observed that the compressive strength of cubes increases continuously up to $75 \%$ limestone replacement with coarse aggregate in concrete mix with $30 \%$ replacement of fly ash with sand in common. The maximum value is obtained at $75 \%$ limestone replacement at both ages. And then decrease at $100 \%$ limestone replacement.

\section{Split tensile strength Results}

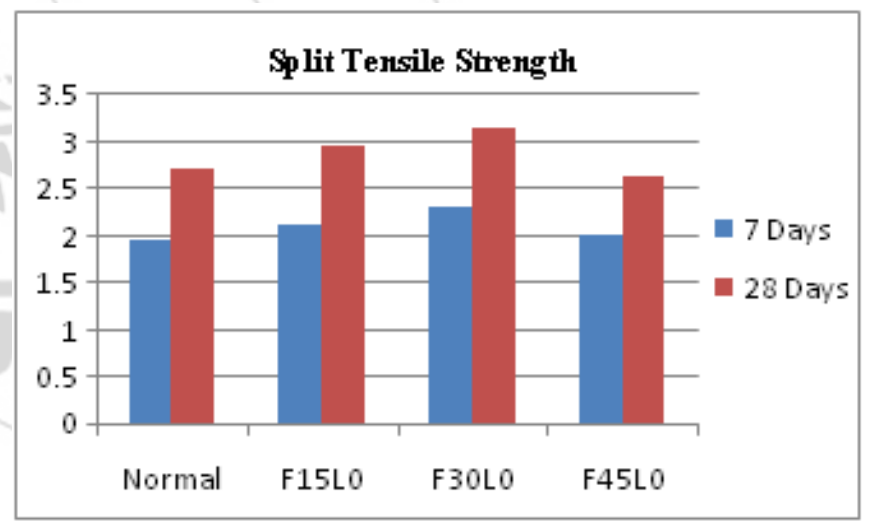

Figure 6: Split tensile strength of fly ash Replacements

From the Fig. 6 it is observed that the split tensile strength of cylinders increase at $30 \%$ fly ash replacement with sand compared to conventional concrete and then decrease at $45 \%$ fly ash replacement at both $7 \& 28$ days ages.

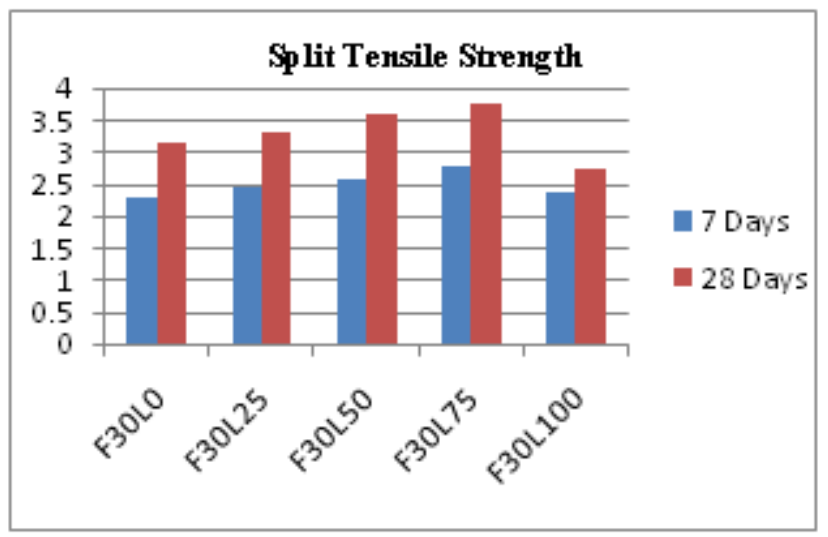

Figure 7: Split tensile strength of optimum fly ash and varying Limestone Replacements 


\section{International Journal of Science and Research (IJSR) \\ ISSN (Online): 2319-7064 \\ Index Copernicus Value (2013): 6.14 | Impact Factor (2015): 6.391}

Form the Fig. 7 it is observed that the split tensile strength increases continuously as the limestone replacement percentage is increase up to $75 \%$ replacement and then decrease for $100 \%$ Limestone replacement at both $7 \& 28$ days ages.

\section{Flexural tensile strength test}

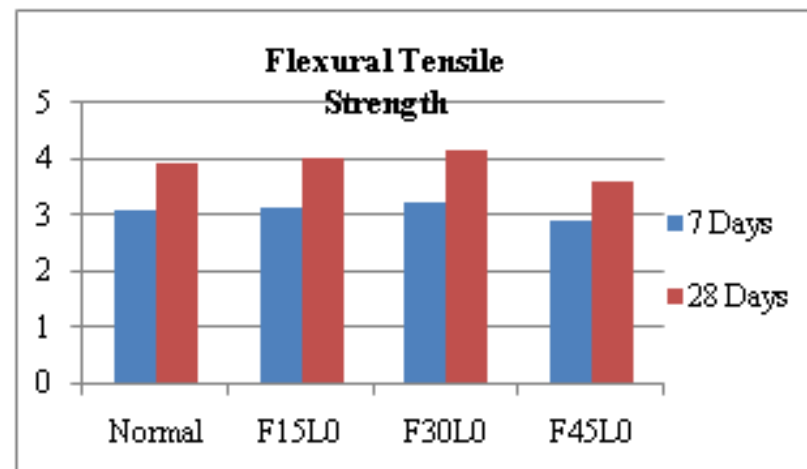

Figure 8: Flexural tensile strength of fly ash Replacements

From the Fig. 8 it is observed that the flexural tensile strength increases up to $30 \%$ fly ash replacement and then decreases for $45 \%$ fly ash replacement for both ages.

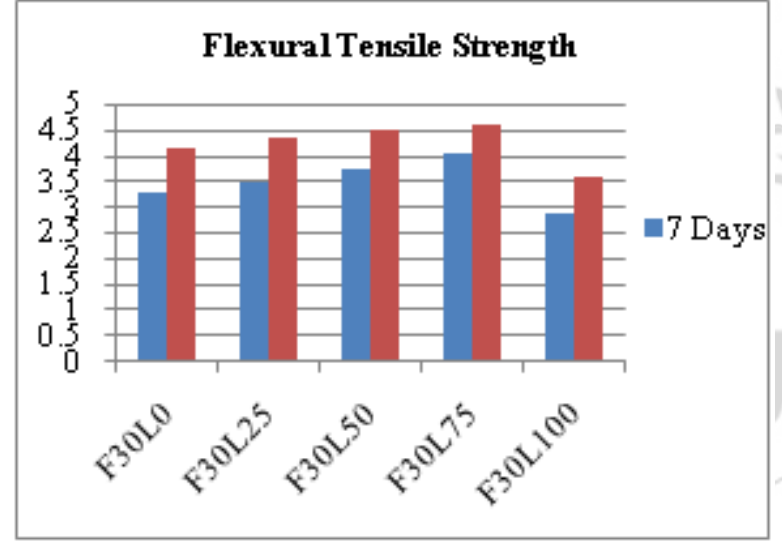

Figure 9: Flexural tensile strength of optimum fly ash and varying Limestone Replacements

From the fig. 9 it is observed that the flexural strength increases continuously as the limestone replacement increase in concrete mixes up to $75 \%$ at both the ages.

\section{E. Water absorption test}

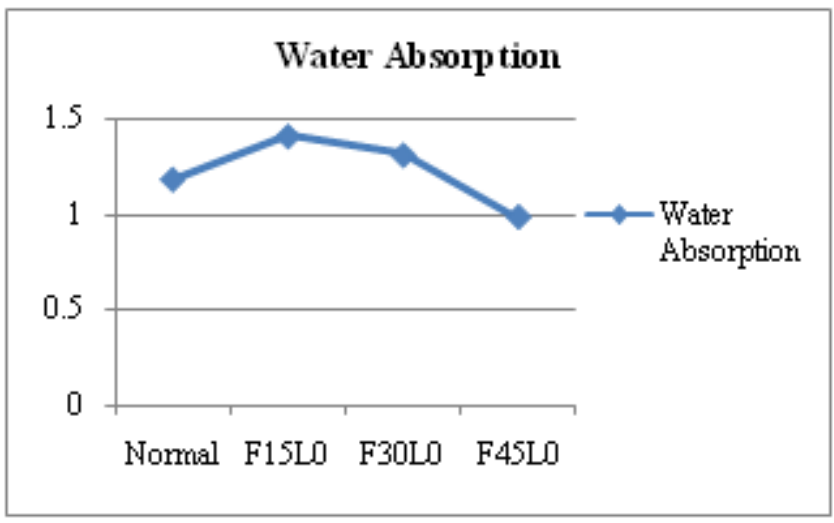

Figure 10: Water absorption of fly ash Replacements
From the Fig. 10 it is observed that water absorption of concrete cubes containing $15 \%$ of fly ash as sand replacement material is higher compared to conventional concrete cubes. But then after the water absorption of cubes decreases up to $45 \%$ of fly ash replacement. The water absorption at $45 \%$ fly ash replacement is found to be lower compared to conventional concrete.

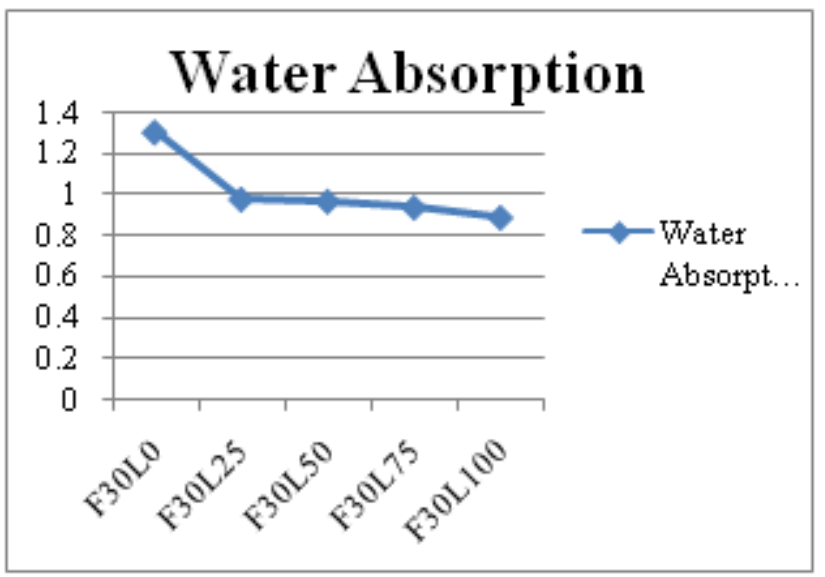

Figure 11: Water absorption of optimum fly ash and varying Limestone Replacements

From the Fig. 11 it is observed that the water absorption of concrete cubes decrease as the limestone replacement $\%$ is increase in concrete. This may be due to low water absorption of limestone aggregates compared to crushed coarse aggregates

\section{Conclusion}

The following conclusions can be drawn from the present investigation.

1. Compressive strength, splitting tensile strength and flexural strength of fine aggregate (sand) replaced fly ash concrete specimens are higher compared to the plain concrete (control mix) specimens up to $30 \%$ fly ash replacement at the ages of $7 \& 28$ days.

2. Compressive strength, splitting tensile strength and flexural strength of fine aggregate (sand) replaced fly ash concrete continued to increase up to $30 \%$ fly ash content and then decrease for $45 \%$ fly ash content at the ages of $7 \& 28$ days

3. Compressive strength, splitting tensile strength and flexural strength increases continuously for the limestone replacement \% with coarse aggregate up to $75 \%$ and then decreases for $100 \%$ replacement in concrete mixes at the ages of $7 \& 28$ days.

4. The maximum compressive strength, split tensile strength and flexural strength occurs with $30 \%$ fly ash and $75 \%$ limestone content at both ages. And it is respectively $27.11 \mathrm{MPa}, 2.78 \mathrm{MPa}, 4.06 \mathrm{Mpa}$ at 7 days and $32.59 \mathrm{MPa}, 3.75 \mathrm{MPa}, 4.62 \mathrm{Mpa}$ at 28 days.

5. So, it is desirable to replace fly ash up to $30 \%$ with fine aggregate and limestone up to $75 \%$ with coarse aggregate in concrete.

6. The workability and water absorption of concrete mixes decreases continuously as the percentage replacements of fly ash and limestone with fine aggregate and coarse aggregate increase, respectively. 


\section{International Journal of Science and Research (IJSR) \\ ISSN (Online): 2319-7064}

Index Copernicus Value (2013): 6.14 | Impact Factor (2015): 6.391

7. The results show that it is possible to obtain a medium weight concrete of a desirable strength by using the limestone as coarse aggregate and fly ash as fine aggregate.

\section{References}

Papers

[1] Mazin T. Quttan, Ali Hussain Ali, Eman A. Qasim, “ Crushed Limestone as Coarse Aggregate in Concrete Blocks", 29 December, 2009.

[2] Dr. Muyasser M. Jomma'h, "Using of Local Limestone as Aggregate in Concrete Mixture," Tikrit Journal of Engineering science, volume 19, March 2012, 35 - 43.

[3] Turan OZTURAN, Cengizhan Cecen, "Effect of Coarse Aggregate Type on Mechanical Properties of Concretes with Different Strengths", Elsevier Journal (Cement and Concrete Research, Volume 27), 8 January 1997, 165170.

[4] Rafat Siddique, "Effect of fine aggregate replacement with Class F fly ash on the Mechanical properties of concrete", Cement and Concrete Research, 16 September 2002, 539-547.

[5] Aruna Kanthi E. and Kavitha M., "Studies on Partial Replacement of Sand with Fly ash in Concrete", European Journal of Advances in Engineering and Technology, 2014, 89-92.

[6] Anjana Chandran A., Anchel A. S., Sudheer K. V., "Effect of Fine Aggregate Replacement with Class F Fly ash and Coppers Slag on Strength Properties of Concrete", International Journal of Advanced Research Trends in Engineering And Technology (IJARTET), March 2015, 66-70.

[7] Abdulrahman M. Alhozaimy, "Effect of absorption of limestone aggregates on strength and slump Loss of concrete", Elsevier Journal, 2009, 470-473.

[8] Ke-Ru Wu, Bing Chen, Wu Yao, Dong Zhang, "Effect of coarse aggregate type on mechanical properties of high-performance concrete", Cement and Concrete Research, 20 June 2001.

[9] Parvati V. K, Prakash K.B, Feasibility Study of Fly Ash as a Replacement for Fine Aggregates In Concrete and its Behaviour Under Sustained Elevated Temperature ", International Journal Of Scientific \& Engineering Research, 5 May 2013, 87-90

\section{Websites}

[1] "The Effect of Aggregate Properties on Concrete", http://www.engr.psu.edu/ce/courses/ce584/concrete/libr ary/materials/aggregate/aggregatesmain.htm

[2] Pascal Peduzzi , "Sand, rarer than one thinks", MARCH

2014 , http://na.unep.net/geas/getUNEPPageWithArticleIDScri pt.php?article_id $=110$

[3] "CRUSHED LIMESTONE CONCRETE AGGREGATE",

http://www.texascrushedstoneco.com/2012/03/crushedlimestone-concrete-aggregate-2/

[4] http://www.sandatlas.org/limestone/

[5] "EFFECTS OF AGGREGATE PROPERTIES ON CONCRETE", $\quad$ December $31, \quad 2015$, http://theconstructor.org/concrete/effects-of-aggregateproperties-on-concrete/5555/

[6] http://www.cement.org/for-concrete-bookslearning/concrete-technology/concrete-designproduction/use-of-aggregates-in-concrete

[7] K.RAJA, "Complete information on production and distribution of Limestone in India", http://www.preservearticles.com/2012020422770/compl ete-information-on-production-and-distribution-oflimestone-in-india.html

[8] "Highlights of Mineral Production", April 2013 to March 2014 , http://ibm.nic.in/writereaddata/files/10202014112509ms mpmar14_07_Highlights_Eng.pdf

[9] “Limestone",http://www.miningoilgasjobs.com.au/mini ng/rocks,-metals---gems/rocks/limestone.aspx

[10]Dirk Braen, "Crushed Limestone Uses \& Benefits", October 29, 2014, http://www.braenstone.com/2014/10/crushed-limestone/

[11] http://www.caer.uky.edu/kyasheducation/glossary.shtml

[12] http://www.engineeringcivil.com/workability-of-freshconcrete-by-compacting-factor-test.html

\section{Dissertation}

[1] MUSFA BIN MOHAMAD, Thesis Master of Engineering (Civil Structure) "THE USE OF LIMESTONE AGGREGATE IN CONCRETE", UNIVERSITI TEKNOLOGI, MALAYSIA, 4 April, 2005 